\title{
Nexus between foreign direct investment, foreign aid, foreign remittance and economic growth in Bangladesh: Analysis of association
}

\author{
Shah Asadullah Mohd. Zobair \\ Department of Economics and Banking \\ International Islamic University Chittagong (IIUC), Bangladesh \\ Myne Uddin \\ MSS Student, Department of Economics and Banking \\ International Islamic University Chittagong (IIUC), Bangladesh
}

\begin{abstract}
This study aims at exploring time series data of economic growth indicator and foreign inflow of fund to Bangladesh to investigate the nature of impact of such fund inflows on economic growth. In this regard data has been collected from World Bank data base for a period ranging from 1976 to 2017. The analysis is conducted by using the ARDL approach. The study identified foreign direct investment as a crucial external factor for growth of Bangladeshi economy. But another two mentionable ways of fund inflow such as foreign aid and remittance are found to play negative role in this regard. Along with these findings, this study recommends that the competent authority of Bangladesh should focus on creating more investment friendly environment to attract and ensure continual of foreign investment. Additionally, the study also claims for proper action to ensure effective use of policy and rules to make the best use of foreign aid and ensure enhanced capital formation of the foreign remittance.
\end{abstract}

Keywords Economic growth, FDI, foreign aid, foreign remittance, ARDL, Bangladesh economy

Paper type Research paper

\section{Introduction}

Growth of the economy is very essential because a strong economic growth has a great opportunity to control unemployment, reduce poverty, improve living standard and increase educational quality and health conveniences. In the globalized world economy, it becomes very difficult to identify what truly determines economic growth. Growth of economy is largely shaped by some external determinants along with internal determinants such as sound macro-economic strategies, good governmental system, skilled human capital,

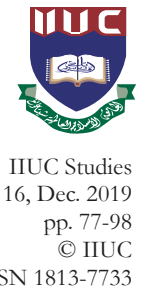

ISSN 1813-7733 
stability in a political issue, and savings (Narayan \& Smyth, 2005; Romer, 1986; Roubini \& Wachtel, 1999; Solow, 1956). Foreign remittance and aid from abroad are being considered remarkable external determinant along with the most crucial foreign direct investment (FDI). Among the external determinants, foreign direct investment, foreign remittance, and foreign aid are being considered crucial.

In developing country, FDI plays a pivotal role leading to boosting economic growth. It enhances foreign exchange reserve as well as ensures investment within the economy. FDI helps an economy by fostering employments. FDI has a dynamic ability to facilitate the capital arrangement, transfer modern technology and knowledge, and generate employment opportunity which ultimately affects the economic growth in a positive way (Al-Iriani, 2007). FDI results spillovers when host country get knowledge, as trained workers and executives working at foreign organizations are likely be connected with local workforces (Glass \& Saggi, 2002). FDI has a positive relationship with domestic investment since later one could adopt infrastructure, developed through FDI (Sylwester, 2005). Despite such blessings, the support of FDI towards economic progress is subject to some criticisms. Some instances are found dictating negative association (Hermes \& Lensink, 2003; Lipsey, 2000). Sometimes the host countries BOP decreases due to large amount of benefits or profit which are expatriated by foreign investors (Kentor, 1998). Some instances also found dictating inverse impact of FDI not only on economic enhancement but also on accumulated savings and investment at domestic level (Fry, 1993).

According to OECD, government aid refers to the formal development support aiming at socio economic betterment and welfare enhancement in developing country like Bangladesh. Most of the third world countries nations conspicuously depend on foreign aid to contribute in trade gap and to fund savings-investment gap. A World Bank investigation suggests that when there are sound policy and environment then aid becomes effective for a country (Burnside \& Dollar, 1997). As per Keynesian model, foreign aid may enhance consumption, which is a very crucial factor in economic growth. It leads to confidence of claiming positive association between economic enhancement and aid from abroad (Feeny, 2007; Juselius, Møller, $\&$ Tarp, 2014). Though the 3rd world countries are significantly depending on foreign aid but some instances are found that questioned the role of foreign aid towards economic growth. Many instances are found that claim corruption in management of foreign aid reduces effectiveness (Alesina \& Weder, 2002). Some perils such as high corruption level, undesired institutional quality, lack of strong law implementation and accountability are 
distorting the positives outcomes that are expecting from foreign aid (Bräutigam \& Knack, 2004). In some countries, foreign aid is misused by financing inefficient and corrupted government, importing unsuitable technology and distorting local income distribution (Bobba \& Powell, 2007; Ekanayake \& Chatrna, 2010). Sometimes foreign aid is used as non-productive expenditure like expenditure of government consumption, which ultimately decreases the tax and domestic savings (Ouattara, 2007). The nature of outcomes of foreign aid depends on contributors' practices(Djankov, Montalvo, \& Reynal-Querol, 2009).

In developing countries, foreign remittance promotes and stimulates the economic growth, enhances the investment capacity and decreases the liquidity constraints (Giuliano \& Ruiz-Arranz, 2009). Foreign remittance helps developing countries reduce poverty level (Jongwanich, 2007) and contributes to socio-economic development (Barai, 2012; Rao \& Hassan, 2012). In case of monetary benefits, foreign remittance has a great contribution to a country's educational development, increasing health facilities and gender equality which ultimately leads to the human development of a country. Therefore, these earnings support the poor people of the country and increase their income level for the individuals and also for their families (Ratha, 2013). Remittances inflows of the workers are utilized for the repayment of the loan which is taken to finance insurance, education or migration process and strategic purposes (Docquier \& Rapoport, 2005). Despites all these positive outcomes, in some cases foreign remittances are found neutral and sometimes, as negative determinants of economic growth. Members of family that receives remittance from abroad become less interested to work (Chami, Fullenkamp, \& Jahjah, 2005). Most of the time workers remittances are used for the purposes of conspicuous consumptions and not for the purposes of investment (Ellerman, 2003; Looney, 1990).

From the global perspective, instances of both positive and negative arguments are found regarding the impact of FDI, foreign aid and remittance on economic growth. This study aims at investigating how these factors influence economic growth of Bangladesh.

The following part of the study would start with a coherent literature review to examine the researches that aimed at exploring influence of FDI, remittance and foreign aid on betterment of economy. The literature review would be followed by a precise addressing of methodology to be adopted in this research. Finally, the influence of mentioned external factors on economic growth would be examined by using ARDL (acronym of Autoregressive Distributed Lag) Bounds testing approach. 


\section{Literature review}

From the study of different researches, both positive and negative relationship are found between economic growths and inflow of funds such as FDI, foreign remittance and aid. Some researchers claim such relationship as neutral. The studied key researches are summarized here.

Remarkable researches claim both positive and negative impact of FDI on development of economy. Besides, some researchers concluded by claiming growth of economy is independent of FDI. Such as, an investigation of panel data of 84 countries identified a positive cause effect association between development of economy and FDI based on human capital interaction ( $\mathrm{Li} \& \mathrm{Liu}, 2005)$. Another investigation suggests that FDI contributes to the host countries economic development with the transfer of knowledge, managerial skills, ideas and technologies (Mengistu \& Adams, 2007). The expected outcome of the FDI to both investor and hos country depends on availability of sound business environment (Buckley, Clegg, \& Wang, 2002). The benefits of FDI are subjected to the trained human resources, advanced technology, improved infrastructure, institutional and macroeconomic reforms, open trade policy and friendly policies for FDI (Borensztein, De Gregorio \& Lee, 1998; Makki \& Somwaru, 2004). A study about 46 countries suggests that FDI keeps a very strong influence on growth of economy when the workforce of the host country is highly skilled and developed (Balasubramanyam, Salisu, \& Sapsford, 1996). A study using data from the period of 1972 to 2008 argues for negative impact of FDI on growth of economy (Siddiqui \& Iqbal, 2010). Another investigation concern with probable negative externality from FDI, because of the emergence of a large number of the multinational company into the domestic market, the competition of the market increased which forced local company to reduce the level of production and that ultimately reduces the efficiency (Jordaan, 2008). The theory of dependency claims that the economic betterment of the host country is influenced negatively by foreign investment (Dutt, 1997). Another investigation supports that dependency theory where the study argues that when FDI finance companies grabbed excessive profits to their own country then the FDI influenced the economic growth negatively (Brecher \& Alejandro, 1977). The experts claim that a country's development is adversely influenced by FDI (Eller, Haiss, \& Steiner, 2005). In another study it is concluded that because of crowding out of the domestic investment, there is a possibility of generating monopoly, and FDI is responsible for creating such kind of monopoly (Bornschier, 1985). A study on Turkey claimed mixed effect of FDI on local economy development (Ilgun, Koch, \& Orhan, 2010). A panel data based study find any base to 
FDI, aid, remittance: economic growth 81

consider FDI as one of external determinants of economic progress (Carkovic \& Levine, 2005). Another investigation in Turkey where the study investigates the relation among FDI, import, export, and growth by using quarterly data from 1991Q1 to 2007Q3, finds economic growth is independent of FDI (Yllmazer, 2010).

The study about the positive outcomes of foreign aid to economic progress in South Korea, suggests that to overcome numerous challenges of the country and to help the various development venture and also for enhancement of the overall economic growth, foreign aid plays a very vital role. The study additionally infers that for the utilization of foreign aid and to perform a dynamic role by foreign aid, a solid and sound government commitment is very essential (Kim, 2011). A research conducted on some less developed African claimed foreign aid as key influencing factor of economic growth along with domestic savings (Irandoust \& Ericsson, 2005). Another investigation about Melanesia claims economic betterment is positively influenced by foreign aid (Feeny, 2007). Such relationship also found by a study on economy of Nepal (Bhattarai, 2009). Foreign aid is a significant determinant of welfare of socioeconomic condition of economy since it has both direct and indirect impact on poverty alleviation (Addison, Mavrotas, \& McGillivray, 2005; Mosley, Hudson, \& Verschoor, 2004). Another investigation with two-sector model and data from 1972 to 1982 argues that foreign aid influences the economy positively in Bangladesh (Rahman, 1984).

In contrast, some investigations claim negative influence of foreign aid on development of economy in many countries. A study demanded good governing policy of foreign aid for positively linking with growth of economy (Ali \& Isse, 2005). But a research defend this claim by arguing that foreign aid might be a peril of economic slowdown even at the presence of proper management of such fund (Rajan \& Subramanian, 2008). The study by using the OLS and 2SLS methods about the 32 Sub-Saharan African countries to investigates relationships among foreign aid, governance and institutions and the investigation finds that, foreign aid hampered the quality of the governance, foreign aid is negatively connected with the tax share of the GDP, and the researchers also stress that when a country over long periods of time receive a huge amount of foreign aid, it decreases the institutional quality and create incentives for foreign aid agencies (Bräutigam \& Knack, 2004). Such finding is also supported by another investigation where the investigators suggest that foreign aid may deteriorate good governance and they also argue that aid is associated with the worsening of economic and political institutions(Sarwar, Hassan, \& Mahmood, 2015). 
Research findings are also found that claim foreign remittance as both negative and positive determinant of socioeconomic development. There are also some arguments that there is no significant relationship. Studies exploring impact of foreign remittance on economic development advocates for positive impact in developing countries since it helps to boost foreign reserve (Ahmed, Zaman \& Shah, 2011; Nwaogu \& Ryan, 2015). The study based on a panel of Andean countries indicated a positive relationship among the remittance and the economic growth (Solimano, 2003). A study with 37 African countries suggests that remittance boost economic growth although their financial system is not so good (Ekanayake \& Mihalis, 2008). A study using data about 20-27 countries reported that remittance influence real GDP per capita growth positively in Asian countries during 1988-2007 (Vargas-Silva, Jha \& Sugiyarto, 2009). A study exploring economic data of 62 developing countries from the period of 1990 to 2014 indicates that when the countries are more open, the remittance boosts the growth. Beside this, this study also claims that the cause behind this happening is that remittance is in itself not adequate for growth, the benefits of the remittance are depended on the macroeconomic environment and the quality of the domestic institution of the remittance receiving country (Dastidar, 2017).The investigation in MENA countries with data from 1980 to 2009 claimed influences of remittance indicates that the remittance stimulates the economic growth when the remittance is invested and it also contributes to growth by boosting the accumulation of human capital (Mim \& Ali, 2012). A study of 8 labor-exporting MENA countries claimed influence of remittance is positive with investment and negative with saving at domestic level (Sabra, 2016). A negative relation between economic progress and remittance is also found in a study based on panel data of 113 countries for a period of 30 years (Chami, Fullenkamp \& Jahjah, 2005). Another investigation points out that one of highest remittance receiving country, Bangladesh experiences negative trend in economic development due to remittance inflow (Ahmed, 2010). There is also the argument that remittance is not efficiently utilized in Bangladesh (Chowdhury, Hamid \& Chatterjee, 2010; Ferdaous, 2016). Neutral impact of remittance inflow on economic fostering is also claimed by many researchers (Barajas, Gapen, Chami, Montiel \& Fullenkamp, 2009; Catrinescu, Leon-Ledesma, Piracha \& Quillin, 2009; Spatafora \& Aggarwal, 2005).

From the summary analysis of above explored researches mixed outcomes regarding impact of some external factors to economy such as foreign aid \& remittance, FDI on development of economy are found. No such significant study has been conducted with purpose of investigating the 
relationship of Bangladeshi economic growth with external fund inflow mechanism such as FDI, foreign aid and remittance all together. Thus an empirical study to explore such relation from the context of Bangladesh would be meaningful for policymakers.

\section{Data, model and methodology}

\subsection{Data collection}

This research is based on secondary data. Annual time series data of decided variables have been collected from World Development Indicators statistics of World Bank for the period of 1976 to 2017. As economic growth indicators the data of GDP has been collected and the log form of GDP has been used as dependent variable in data analysis model. The independent variable FDI, foreign remittance and aid from abroad are used in log form by expressing as percentage of GDP.

\subsection{The model}

This empirical analysis is done by using 42 annual observations from 1976 to 2017. The empirical analysis complete throughout the following model:

LGDP $_{t}=\beta_{o}+\beta_{1}$ LFDI $_{t}+\beta_{2}$ LFAID $_{t}+\beta_{3}$ LFREMT $_{t}+U_{t}$

Where, LGDP $=$ Log of GDP (Gross domestic product) per capita LFDI $=$ Log of FDI (Foreign Direct Investment) LFAID $=\log$ of Foreign Aid LFREMT $=$ Log of Foreign Remittance

$\mathrm{Ut}=$ Disturbance term

$\beta_{0}$ is the constant as well as the intercept of this regression line and $\beta_{1}, \beta_{2}$ and $\beta_{3}$ are the coefficients of all corresponding endogenous independent variables.

\subsection{Estimating methodology}

Stationarity of data has to be examined while the research is based on time series data analysis. Because such variation due to these natures of data, the regression becomes spurious and non-sense. So, it is required to detect a probable no stationary problem in the first instance and to find the order of integration of every series of data. Thus, such problem would be detected by using Unit Root Test. Among the various test, the Augmented Dickey-Fuller (ADF) test is a popular one which is used widely for possible non-stationary fears. When the variables of time series data become non-stationary and the same order of integration of the variables, it is commended that the co-integration method is required to apply for the analysis. There is another argument that it is possible to model in the levels of stationary variables and 
It is also possible to use Granger causality tests, although in case of non-stationary variables, it is possible to detect the long-run relationship by using the co-integration scheme (Akçay \& Demirhan, 2005).

It is practicable that the time series data can be analyzed by using different types of econometric techniques and tools like, Johansen multivariate co-integration, Engle-Granger test and the ARDL (Autoregressive Distributed Lag Models) approach which is recently developed by (Pesaran, Shin \& Smith, 2001) and this is also recognized as very useful. Since it has a strong ability to work with limited and unlimited sample size and also have good control over the different order of co-integration of variables. These tools and techniques mostly depend on the stationary of variables I (1) although the necessity of the variables I (1) sometimes the estimation of the co-integrations test related to biases. Since the available variables of the study recognized as mixed of I (1) and I (0) data series. Accordingly, to detect the long-run relationship of the study would be able to perform the analysis through the ARDL approach to co-integration.

\section{ARDL approach}

Equation (1) is written as the framework of ARDL in following form which would be referred as equation (2)

$L G D P=\beta_{0}+\beta_{1} L G D P_{t-1}+\beta_{2} L F D I+\beta_{3} L F A I D+\beta_{4} L F R E M T+\beta_{5} L F R E M T_{t-2}+U_{T} \cdots 2$ Basically, the ARDL approach to co-integration is performed by mainly two stages. At first, the null hypothesis which is 'no co-integration' is performed. Where the null hypothesis implies that the coefficients of the repressors of the ARDL model are zero alone with the coefficient Error Correction model. It is then suggested that the long-run relationship does not exist between them. And no long-run relationship $\left(\boldsymbol{\beta}_{1}=\boldsymbol{\beta}_{2}=\boldsymbol{\beta}_{3}=\boldsymbol{\beta}_{4}=\mathbf{0}\right)$ as null hypothesis required to examine against the presence long-run relationship $\left(\boldsymbol{\beta}_{1} \neq \boldsymbol{\beta}_{2} \neq \boldsymbol{\beta}_{3} \neq \boldsymbol{\beta}_{4} \neq \mathbf{0}\right)$ as an alternative hypothesis. If the null hypothesis can be rejected it would be confirmed that there is a long-run relationship.

Pesaran (2001) identified two sets of values, those are referred to as the lower limit of critical value and upper limit of critical value. The Wald coefficient test is required to run to impose the limitations on the coefficient of long-run and the attain Wald F-statistic and it is also required to compare with the upper limit of critical values and lower limit of critical values which is developed by (Pesaran, Shin \& Smith, 2001). The possible results would be of three kinds concerning the relationship of co-integration among the variables. Co-integration exists when Wald F-statistics produces a value higher than critical value's upper limit while a Wald F-statistic value less than 
critical value's lower limit means no existence of co-integration. If the calculated Wald F-statistics lies within the range of upper limit and lower limit then the decision about the co-integration would be indecisive. Again (Narayan, 2004) has re-established and suggests another the critical values for the ARDL method when the sample size of the observation between 30 to 80. In this case, the (Narayan, 2004) provided critical values are effective since the time period of this study constrained by 41 observations. Subsequently, to attain the decision related to co-integration relation it should be followed (Narayan, 2004) critical values to compare the calculated Wald F-statistics.

The next stage is to investigate the short-run dynamics for which it is required to examine an error correction model and this is also needed to examine the stability of the long-run parameters. The error correction model is identified by the following equation (2):

$$
\begin{aligned}
\Delta(L G D P)= & \beta_{0}+\beta_{1} \Delta(L F D I)+\beta_{2} \Delta(L F A I D)+\beta_{3} \Delta(L F R E M T)+\beta_{4} \Delta(L G D P)_{t-1}+\beta_{5} \Delta(F D I)_{t-1} \\
& +\beta_{6} \Delta(L F A I D)_{t-1}+\beta_{7} \Delta(L F R E M T)_{t-1}+\beta_{8}(E C M)_{t-1}+U_{t} \ldots \ldots . .3
\end{aligned}
$$

Here, ECM refers to the error correction term. The expectation of the relation between the dependent variable and ECM is negative. ECM would be calculated by running the long-run ARDL equation (2).

\section{Estimation and analysis}

\subsection{Unit root analysis}

A study with selected time series data is needed to review that the uses data of the variable either have stationary or non-stationary in their nature. Since there is a probability of spurious results of the regression. When a variable of time series data which has a constant mean and also has constant variance over the time then it refers to stationary and value of covariance among two periods of time are depends only on the distances among the two time periods of time and does not depends on the genuine time at when it is calculated (Gujarati, 2009).

In a different technique, it is possible to check the stationary of the variables of time series data and the standard method is the unit root tests. Unit root tests can be executed with different tests and one of the most famous methods are the Augmented Dickey-Fuller (ADF) test and Phillips-Perron (PP) test. They are used to identify whether the variables of this study are stationary or not.

The rules of decision making of this test is that if the p-value of the $\mathrm{ADF}$ test is less than $5 \%$ then the null hypothesis would be rejected which 
means alternative hypothesis would be accepted Otherwise, it is not possible to reject the null hypothesis. If the $\mathrm{ADF}$ unit root test is greater than the $5 \%$ critical value of the obtained t-statistic value, the null hypothesis will not be accepted. Otherwise, it cannot be rejected at the same critical value. When the null hypothesis would be rejected which would mean that the variable has no unit root that means data are stationary. If data are found stationary at level, the result of a regressed by these data will not be spurious (Gujarati, 2009).

Table 1: Unit root test

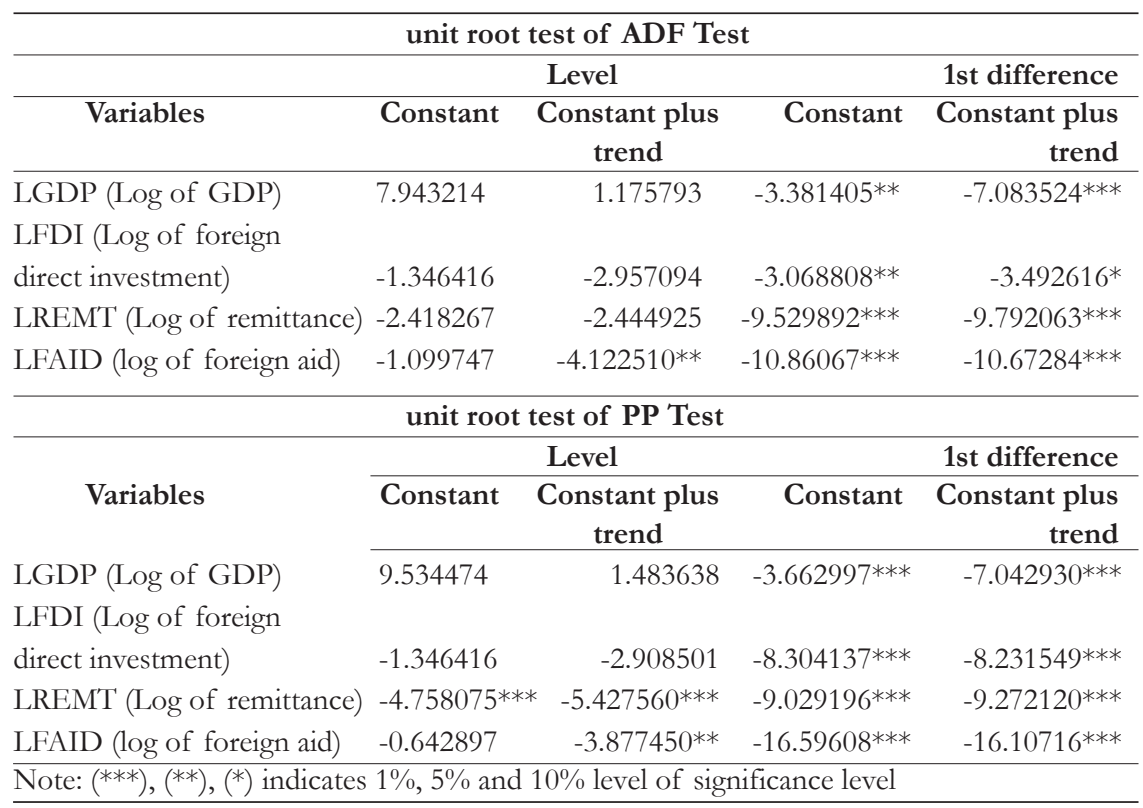

Table 1 shows the ADF test and Phillips-Perron (PP) test results. ADF and PP unit root tests are applied for the variables in their level and first differences and also to intercept and trend simultaneously. The results identified that at levels here all of the variables of the study are non-stationary except LFAID in ADF test and LREMIT, LFAID in PP test. Hence, LFAID and LREMIT are integrated order of zero $\sim \mathrm{I}(0)$. However, all variables other than these two variables are stationary at first difference in both ADF and PP tests, hence they are integrated order of one I(1). This implies that it is needed to apply ARDL model as there exists mixes of I(1) and $\mathrm{I}(0)$ along with the co-integration (bound) test.

4.2. Co-integration test

Here we applied bound test to confirm that either co-integration exists or not. The co-integration refers to the long-run relationships of the projected 
variables. If the f-statistic computed value becomes more than the upper limit at $1 \%, 5 \%$ or $10 \%$ level of significance which indicates do not accept the null hypothesis which is no long-run relationship. And ultimately it is certified that the co-integration exists and there are long-run relationships among the variables.

Table 2: Co-integration test

\begin{tabular}{lccc}
\hline Co-integration test (bound test) & \multicolumn{2}{c}{ Wald Test (F-Value) } \\
\hline Level of Significance & \multicolumn{2}{c}{ Critical values } & \\
\cline { 2 - 3 } & Lower Limit & Upper Limit & \\
\cline { 2 - 4 } $1 \%$ & 4.29 & 5.61 & 14.71270 \\
$5 \%$ & 3.23 & 4.35 & \\
$10 \%$ & 2.72 & 3.77 & \\
\hline
\end{tabular}

Table 2 represents the outcomes of the bound test. The outcomes of the Wald F-test which are stated in table 02 with critical values. Here the value of the Wald F-test is 14.71270 which is calculated value of with lag 3, which is greater than the critical value of upper bound at 1\%,5\%,10\% level of significance. Consequently, the variables are co-integrated which is determined by the above results.

\subsection{ARDL estimation}

According to the last discussion, it is confirmed that the selected variables of the study are truly co-integrated. To recognize the long-run relationship among the dependent and independent variables it is needed to estimate the ARDL model. The variables with different lags can be used (Duasa, 2007). Estimated ARDL model is the following:

Table 3: ARDL model

\begin{tabular}{lcccr}
\hline Panel (A) & \multicolumn{5}{c}{ T-Scores } & Probability \\
\hline Variables & Coefficients & Std. Error & -2.733090 & 0.0098 \\
\hline CONSTANT & -0.443059 & 0.162109 & 54.79838 & 0.0000 \\
LGDP(-1) & 1.11407 & 0.018457 & 1.964950 & 0.0574 \\
LFDI & 0.182309 & 0.093340 & -1.809494 & 0.0790 \\
LFAID & -0.012146 & 0.006713 & -2.529244 & 0.0161 \\
LFREMT & -0.027062 & 0.010700 & 2.257238 & 0.0303 \\
LFREMT(-1) & 0.016705 & 0.007400 & & \\
\hline Panel (B) Diagnostic Checking & & & & \\
R-squared & & 0.999051 & Ramsey RESET test & 0.492246 \\
Adjusted R-squared & & 0.998915 & Durbin-Watson stat & 2.098568 \\
LM -test & & 0.058115 & & \\
Heteroskedasticity test & & 0.894819 & & \\
Jarqure-Bera & 0.099411 & & \\
\hline
\end{tabular}


Here panel A of Table 03 shows the outcomes of the ARDL model. And the panel B of the table of 03 shows the results of different diagnostic tests to ensure the reliability of the model.

All of the results from different diagnostic tests confirmed that the estimated ARDL model is free from all kinds of econometric problems. LM test guaranteed that the model is free from any type of serial correlation problem. It is also identified that there is no heteroskedasticity problem. It is confirmed that the model specification is correct and the error is normally distributed which are indicated by Jarque-Bera and Ramsey RESET test. The model is not spurious which is clearly recognized by the Durbin-Watson value. According to the value of $\mathrm{R}$ Square, it can be recognized that the model is best fitted, the high-value R square (0.998915) which indicates that the independent variables explained about $99.90 \%$ variation of the dependent variable. Therefore, the ARDL model is found reliable.

\section{Results}

\subsection{Discussion of results}

Table 03 represents the results of the ARDL model. At 10\% level of significance the economic progress of Bangladesh is positively related with FDI. Whenever the FDI is increased by 1\% then an increase of $0.183409 \%$ would be happened for GDP. This outcomes from the investigation in Bangladesh is also supported by many remarkable studies (Al-Iriani, 2007; Almfraji \& Almsafir, 2014; Mengistu \& Adams, 2007; Wang \& Blomström, 1992).

The local country's economic development is influenced by FDI positively because of several reasons. By attracting FDI, a host country would be able to adopt advanced technology and modern efficient production methods. Bangladesh should struggle hard for attracting more and more FDI with providing various types of facility to foreign investors such as tax holidays, better and sound infrastructure, cheap and adequate energy resources. FDI has the possibility of increasing the new job opportunity, modern technological advancement and transfer and eventually boast economy. The channels for technology transfer are the transmutation, competition, modern skills and good relationship (Wang \& Blomström, 1992) It is also proposed that in case of developing countries FDI has a dynamic ability to facilitate capital arrangement, to transfer modern technology and knowledge, and to generate employment opportunity which foster socioeconomic condition (Al-Iriani, 2007).

The analysis identifies foreign aid having negative association with been found that a one percent growth in foreign aid would result 0.012146 percent 
FDI, aid, remittance: economic growth 89

decline in GDP. This result designates that foreign aid has a negative influence upon the economic growth of Bangladesh. This results concerning the effect on economic growth are also reliable with other investigations (Alamgir, 1974; Bobba \& Powell, 2007; Ekanayake \& Chatrna, 2010; Griffin \& Enos, 1970; Ouattara, 2007; Peter, 1972; Rajan \& Subramanian, 2008; Weisskopf, 1972).

The growth of foreign aid-receiving countries is influenced negatively by foreign aid because of numerous reasons. It is claimed that the developing countries are used foreign aid to finance inefficient and corrupt government, to import unsuitable technology and distorts local income distribution (Griffin \& Enos, 1970; Weisskopf, 1972). Most of the foreign aid is used in case of non-productive expenditure like expenditure of government consumption, which is ultimately decrease the tax and domestic savings (Ouattara, 2007) The study about foreign aid argue that it is inimical for economic growth, because it increases the power and strength of the predatory governments with undermining the development of the private sector (Peter, 1972).

This result also shows that remittance has a significant negative effect on GDP at 5\% level of significance. It indicates that an increase of one percent in remittance will leads to 0.027062 percent decrease in GDP. This result denotes that foreign remittance has a negative association with the economic growth of Bangladesh. This results are also consistent with other researches (Ahmed, 2010; Chami, Fullenkamp, \& Jahjah, 2005; Chowdhury, Hamid, \& Chatterjee, 2010; Ellerman, 2003; Looney, 1990).

The economic growth of foreign remittance receiving countries is influenced negatively by foreign remittance because of various reasons. A study about 13 countries, shows that there is a negative effect of remittance on economic growth and the author state that remittance-receiving families decrease their own productive activity since they receive remittance income from abroad which is ultimately decrease the labor supply for developing country (Chami, Fullenkamp, \& Jahjah, 2005). Most of the time workers remittances are used for the purposes of conspicuous consumptions and not for the purposes of investment, because of this reasons it might not be beneficial for the economy (Ellerman, 2003; Looney, 1990)

But one-year lag remittance has a significant positive association with GDP at 5\% level of significance. It suggests that lag foreign remittance will influence the GDP positively.

This model is the best fit as the adjusted R2 value is very high (0.998915), as well as the explanatory variables, can be explained dependent variable by $99.90 \%$. F-statistic value is also high and the corresponding 
probability value is much low. It is found that the F-statistic value is statistically significant. Durbin-Watson value confirms that the model is not spurious. The Durbin-Watson value indicates the serial correlation of residuals. Here a rule of thumb could be considered that considers a test statistics value ranging from 1.5 to 2.5 as normal value. Moreover, in this study error-correcting modeling is used with the purpose of ensuring a sustainable long-run relationship. The use of this modeling is also worthy to allow a deviation from the long-run equilibrium. The outcome of such model is sound enough.

\subsection{The results of Error Correction Model (ECM):}

To understand the pace of disequilibrium adjustment with long-run equilibrium, error correction model is used. The results of ECM model are presented in following table:

Table 04: Result of the Error Correction Model

\begin{tabular}{lcccr}
\hline Panel (A) & & & & \\
\hline Variables & Coefficients & Std. Error & T-Scores & Probability \\
\hline CONSTANT & -0.002314 & 0.004679 & -0.494610 & 0.6244 \\
\hline D(LFDI) & 0.119108 & 0.092310 & 1.290298 & 0.2065 \\
D(LFAID) & -0.003225 & 0.010237 & -0.315069 & 0.7548 \\
D(LFREMT) & -0.032445 & 0.011690 & -2.775464 & 0.0093 \\
D(LGDP (-1)) & 1.064401 & 0.132773 & 8.016711 & 0.0000 \\
D(LFDI (-1)) & 0.007584 & 0.097738 & 0.077595 & 0.9386 \\
D(LFAID (-1)) & -0.001060 & 0.010242 & -0.103490 & 0.9182 \\
D(LFREMT (-1)) & 0.033645 & 0.007923 & 4.246423 & 0.0002 \\
ECM (-1) & -1.086478 & 0.223203 & -4.867666 & 0.0000 \\
\hline Panel (B) & & & & \\
\hline R-squared & & 0.734653 & Heteroskedasticity test & 0.8508005 \\
Adjusted R-squared & & 0.666176 & Durbin-Watson stat & 1.944564 \\
LM-test & & 0.447222 & & \\
Jarque-Bera & & 0.099381 & & \\
\hline
\end{tabular}

From the above table of ECM outcomes, it is seen that at significance level of $1 \%$, the ECM is statistically significant. Here, desirable negative coefficient is also found. Thus, this model could be defined as reliable one. The speed of adjustment is referred by the coefficient of the error correction is 1.086478. This coefficient indicates that disequilibrium at short run could be sorted out at the speed of 0.920 year. In panel B results of the diagnostic tests are confirmed that estimated error correction model is free from any econometric problems.

Here, a relationship between economic growth and other specified endogenous variables are specified that would be existing on short term 
basis. The results indicates that remittance has a significant negative impact on GDP which is supported by (Chami, Fullenkamp, \& Jahjah, 2005; Ellerman, 2003; Looney, 1990) but Foreign aid has an insignificant negative association with GDP which is supported by (Boone, 1996; Easterly, 2001) and FDI has an insignificant positive impact on GDP which is supported by (Carkovic \& Levine, 2005; Ilgun et al., 2010; Y1lmazer, 2010).

\subsection{Stability tests}

To check the structural stability test, recursive least squares has been applied. There is one more test in recursive estimation. Here, the Cumulative Sum of the Recursive residuals (CUSUM) test is worked to detect structural stability of the model.

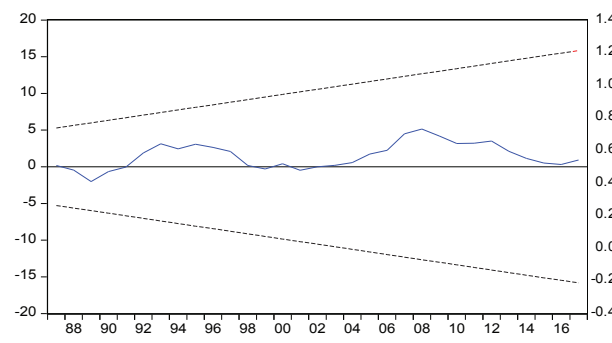

- CUSUM ---- $5 \%$ Significance

Figure 01: CUSUM Test.

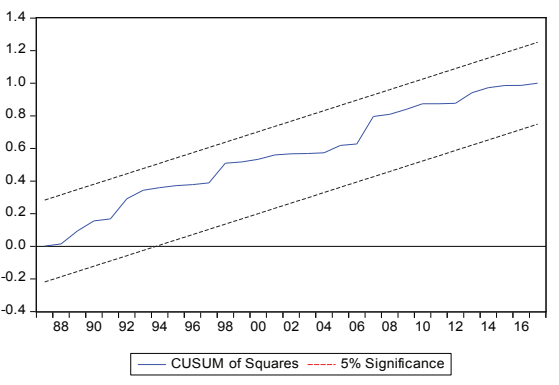

Figure 2: CUSUM of squares.

The above figures dictating stability test outcomes, claim structural stability of the model and assessed the line between the critical limits in case of both CUSUM test and CUSUM of Squares test when the decided level of significance is $5 \%$.

\section{Conclusion}

This research identifies FDI as one of the major factors of economic growth of Bangladesh. This finding of this research is consistent with majority of the research propositions conducted in different economies. Thus, this outcome could be a source of motivation for the policy makers of Bangladesh to be more confident while attracting more FDI.

As external factors, foreign aid and remittances are found in playing negative role to build the economy of Bangladesh. This result is also consistent with other prior empirical investigations. It is difficult to pin down the underlying reasons. The foreign aid is criticized for corruption and anecdotal evidence suggests that the foreign remittance is mainly used for buying land and a small proportion is used on capital formation in Bangladesh. The compositions of foreign aid and foreign remittance, 


\section{IIUC Studies, 16}

measurement issue and data related problem are considered as major perils.

Since FDI has positive relation with economic growth contemporaneously thus the government of Bangladesh should concentrate on elimination of some barriers to FDI such as power shortage and political instability to ensure a business and investment friendly environment. Authority should encourage foreign investors to invest by providing tax holiday in particular sectors or areas and should make business favorable laws to boost up the economic activity. The allocation of foreign aid should be scrutinized carefully to make aid as effective as possible and should take necessary policies and effective control over the level of corruption on foreign aid in Bangladesh which seem to be higher among others south Asian countries. The authority should avoid the use the foreign aid in case of non-productive expenditure and should use to adopt technologies, should utilize in case of health care, education then it may sufficiently enhance the poor empower. It will not be a good policy to unskilled, untrained and illiterate labor more rather than skilled, trained, educated labor and products export to boost up economic growth by receiving foreign remittances. Some family reduce their supply of labor as remittances are received. Strategies should be made about the proper utilization of the inflow of worker's remittance. Bangladesh government should encourage migrated workers and their family by an investment-attracting policy to invest their remittances into the productive field rather than non-productive ones and should make a secure, reliable and profitable opportunity so that the migrants can invest their remittance which may help them when they will return from abroad.

\section{Limitations and directions for future study}

This study explored the impact of FDI, remittance and foreign aid on economic growth of Bangladesh. Though this investigation identified the type of relationship but did not explore the reason behind such relationship from the context of Bangladesh. For instance, this study identified negative outcome of remittance and aid inflow from abroad on economic growth of Bangladesh. But no research based information is given that dictates why such relationship exists in Bangladesh. Thus further research should aim at exploring the reasons behind the identified relationship between growth of Bangladeshi economy and FDI, foreign aid and remittance on the other.

\section{References}

Addison, T., Mavrotas, G., \& McGillivray, M. (2005). Development assistance and development finance: Evidence and global policy agendas. Journal of International Development: The Journal of the Development Studies Association, 17(6), 819-836. 
Ahmed, J., Zaman, K., \& Shah, I. A. (2011). An empirical analysis of remittances-growth nexus in Pakistan using bounds testing approach. Journal of Economics and International Finance, 3(3), 176-186.

Ahmed, M. S. (2010). Migrant workers remittance and economic growth: Evidence from Bangladesh. AS A University Review, 4(1), 1-13.

Akçay, S., \& Demirhan, E. (2005). The causal relationship between openness and economic growth: Evidence from selected MENA countries. Yapi Kredi Economic Review, 16(2), 77-83.

Al-Iriani, M. (2007). Foreign direct investment and economic growth in the GCC countries: A causality investigation using heterogeneous panel analysis. Topics in Middle Eastern and North African Economies, 9.

Alamgir, M. (1974). Foreign capital inflow, saving and economic growth-A case study of Bangladesh. The Bangladesh Economic Review, 2(2), 577-598.

Alesina, A., \& Weder, B. (2002). Do corrupt governments receive less foreign aid? American Economic Review, 92(4), 1126-1137.

Ali, A. M., \& Isse, H. S. (2005). An empirical analysis of the effect of aid on growth. International Advances in Economic Research, 11(1), 1-11.

Almfraji, M. A., \& Almsafir, M. K. (2014). Foreign direct investment and economic growth literature review from 1994 to 2012. Procedia-Social and Behavioral Sciences, 129, 206-213.

Balasubramanyam, V. N., Salisu, M., \& Sapsford, D. (1996). Foreign direct investment and growth in EP and IS countries. The Economic Journal, 106(434), 92-105.

Barai, M. K. (2012). Development dynamics of remittances in Bangladesh. Sage Open, 2(1), 2158244012439073.

Barajas, M. A., Chami, M. R., Gapen, M. T., Fullenkamp, C., \& Montiel, M. P. (2009). Do workers' remittances promote economic growth? Working Paper No. 9-153. International Monetary Fund.

Bhattarai, B. P. (2009). Foreign aid and growth in Nepal: An empirical analysis. The Journal of Developing Areas, 42(2), 283-302.

Bobba, M., \& Powell, A. (2007). Aid and growth: Politics matters, Banco Interamericano de Desarrollo (BID) Research Department Departamento de Investigación Working Paper 601. New York Avenue, Washington, DC: Inter-American Development Bank.

Boone, P. (1996). Politics and the effectiveness of foreign aid. European Economic Review, 40(2), 289-329.

Borensztein, E., De Gregorio, J., \& Lee, J. W. (1998). How does foreign direct investment affect economic growth?. Journal of International Economics, 45(1), 115-135. 
Bornschier, V., \& Chase-Dunn, C. (1985). Transnational corporations and underdevelopment. New York, USA: Praeger.

Bräutigam, D. A., \& Knack, S. (2004). Foreign aid, institutions, and governance in sub-Saharan Africa. Economic Development and Cultural Change, 52(2), 255-285.

Brecher, R. A., \& Alejandro, C. F. D. (1977). Tariffs, foreign capital and immiserizing growth. Journal of International Economics, 7(4), 317-322.

Buckley, P. J., Clegg, J., \& Wang, C. (2002). The impact of inward FDI on the performance of Chinese manufacturing firms. Journal of International Business Studies, 33(4), 637-655.

Burnside, C., \& Dollar, D. (1997). Aid, policies, and growth. World Bank Policy Research Working Paper No. 569252. Washington, DC: World Bank.

Carkovic, M., \& Levine, R. (2005). Does foreign direct investment accelerate economic growth? Does foreign direct investment promote development, 195.

Catrinescu, N., Leon-Ledesma, M., Piracha, M., \& Quillin, B. (2009). Remittances, institutions, and economic growth. World Development, 37(1), 81-92.

Chami, R., Fullenkamp, C., \& Jahjah, S. (2005). Are immigrant remittance flows a source of capital for development? IMF Staff papers, 52(1), 55-81.

Chowdhury, K. R., Hamid, F., \& Chatterjee, D. (2010). Remittance as a tool of economic development: Bangladesh perspective. Bangladesh Research Publications Journal, 4(3), 286-296.

Dastidar, S. G. (2017). Impact of remittances on economic growth in developing countries: The role of openness. Global Economy Journal, 17(2).

Djankov, S., Montalvo, J. G., \& Reynal-Querol, M. (2009). Aid with multiple personalities. Journal of Comparative Economics, 37(2), 217-229.

Docquier, F., \& Rapoport, H. (2005). The economics of migrants' remittances. Handbook on the Economics of Altruism, Reciprocity and Giving, forthcoming. North-Holland: Amsterdam.

Duasa, J. (2007). Determinants of Malaysian trade balance: An ARDL bound testing approach. Global Economic Review, 36(1), 89-102.

Dutt, A. K. (1997). The pattern of direct foreign investment and economic growth. World development, 25(11), 1925-1936.

Easterly, W. (2001). The elusive quest for growth: economists' misadventures in the tropics. Cambridge, Mass: MIT Press.

Ekanayake, E., \& Chatrna, D. (2010). The effect of foreign aid on economic growth in developing countries. Journal of International Business and Cultural Studies, 3, 1. 
FDI, aid, remittance: economic growth 95

Ekanayake, E., \& Mihalis, H. (2008). Do remittances and foreign direct investment promote growth? Evidence from developing countries. Journal of International Business and Economics, 8(1), 58-68.

Eller, M., Haiss, P. R., \& Steiner, K. (2005). Foreign direct investment in the financial sector: the engine of growth for Central and Eastern Europe? Europainstitut Working Papers (69). Vienna, Austria: University of Economics and BA.

Ellerman, D. (2003). Policy research on migration and development, Policy Research Working Paper 3117. Washington, DC: The World Bank.

Feeny, S. (2007). Impacts of foreign aid to Melanesia. Journal of the Asia Pacific Economy, 12(1), 34-60.

Ferdaous, J. (2016). Impact of remittances and FDI on economic growth: A panel data analysis. Journal of Business Studies Quarterly, 8(2), 58.

Fry, M. J. (1993). Some lessons for South Asia from developing country experience with foreign direct investment. World Bank, South Asia Region, Office of the Chief Economist.

Giuliano, P., \& Ruiz-Arranz, M. (2009). Remittances, financial development, and growth. Journal of Development Economics, 90(1), 144-152.

Glass, A. J., \& Saggi, K. (2002). Multinational firms and technology transfer. Scandinavian Journal of Economics, 104(4), 495-513.

Griffin, K. B., \& Enos, J. L. (1970). Foreign assistance: Objectives and consequences. Economic Development and Cultural Change, 18(3), 313-327.

Gujarati, D. N. (2009). Basic econometrics. New York, USA: Tata McGraw-Hill.

Hermes, N., \& Lensink, R. (2003). Foreign direct investment, financial development and economic growth. The Journal of Development Studies, 40(1), 142-163.

Ilgun, E., Karl-Josef, K. O. C. H., \& Orhan, M. (2010). How do foreign direct investment and growth interact in Turkey?. Eurasian Journal of Business and Economics, 3(6), 41-55.

Irandoust, M., \& Ericsson, J. (2005). Foreign aid, domestic savings, and growth in LDCs: An application of likelihood-based panel cointegration. Economic Modelling, 22(4), 616-627.

Jongwanich, J. (2007). Workers' remittances, economic growth and poverty in developing Asia and the Pacific countries. United Nations Publications.

Jordaan, J. A. (2008). Intra-and inter-industry externalities from foreign direct investment in the Mexican manufacturing sector: New evidence from Mexican regions. World development, 36(12), 2838-2854.

Juselius, K., Møller, N. F., \& Tarp, F. (2014). The long-run impact of foreign aid in 36 African countries: Insights from multivariate time series analysis. Oxford Bulletin of Economics and Statistics, 76(2), 153-184. 
Kentor, J. (1998). The long-term effects of foreign investment dependence on economic growth, 1940-1990. American Journal of Sociology, 103(4), 1024-1046.

Kim, J. (2011). Foreign aid and economic development: The success story of South Korea. Pacific Focus, 26(2), 260-286.

Li, X., \& Liu, X. (2005). Foreign direct investment and economic growth: An increasingly endogenous relationship. World development, 33(3), 393-407.

Lipsey, R. E. (2000). Inward FDI and economic growth in developing countries. Transnational Corporations, 9(1), 67-96.

Looney, R. E. (1990). Macroeconomic impacts of worker remittances on Arab world labor exporting countries. International migration (Geneva, Switzerland), 28(1), 25.

Makki, S. S., \& Somwaru, A. (2004). Impact of foreign direct investment and trade on economic growth: Evidence from developing countries. American Journal of Agricultural Economics, 86(3), 795-801.

Mengistu, B., \& Adams, S. (2007). Foreign direct investment, governance and economic development in developing countries. Journal of social political and economic studies, 32(2), 223.

Mim, S. B., \& Ali, M. S. E. (2012). Through Which Channels Can Remittances Spur Economic Growth in MENA Countries? Economics: The Open-Access, Open-Assessment E-Journal, 6 (2012-33): 1-27. doi: http:/ /dx.doi.org/10.5018/economics-ejournal.ja.2012-33

Mosley, P., Hudson, J., \& Verschoor, A. (2004). Aid, poverty reduction and the 'new conditionality'. The Economic Journal, 114(496), F217-F243.

Narayan, P. (2004). Reformulating critical values for the bounds F-statistics approach to cointegration: An application to the tourism demand model for Fiji (Vol. 2, No. 04). Australia: Monash University.

Narayan, P., \& Smyth, R. (2005). Trade liberalization and economic growth in Fiji. An empirical assessment using the ARDL approach. Journal of the Asia Pacific Economy, 10(1), 96-115. doi: 10.1080/1354786042000309099

Nwaogu, U. G., \& Ryan, M. J. (2015). FDI, foreign aid, remittance and economic growth in developing countries. Review of Development Economics, 19(1), 100-115.

Ouattara, B. (2007). Foreign aid, public savings displacement and aid dependency in Cote d'Ivoire: An aid disaggregation approach. Oxford Development Studies, 35(1), 33-46.

Pesaran, M. H., Shin, Y., \& Smith, R. J. (2001). Bounds testing approaches to the analysis of level relationships. Journal of Applied Econometrics, 16(3), 289-326. 
FDI, aid, remittance: economic growth 97

Peter, B. (1972). Dissent on Development: Studies and debates in development economics. Cambridge: Harvard University Press.

Rahman, A. (1984). Foreign aid and self reliant growth: The case of Bangladesh. Dhaka: Center for Social Studies, Dhaka University.

Rajan, R. G., \& Subramanian, A. (2008). Aid and growth: What does the cross-country evidence really show? The Review of Economics and Statistics, 90(4), 643-665.

Rao, B. B., \& Hassan, G. M. (2012). Are the direct and indirect growth effects of remittances significant? The World Economy, 35(3), 351-372.

Ratha, D. (2013). The impact of remittances on economic growth and poverty reduction. Policy Brief, 8(1), 1-13.

Romer, P. M. (1986). Increasing returns and long-run growth. Journal of Political Economy, 94(5), 1002-1037.

Roubini, N., \& Wachtel, P. (1999). Current-account sustainability in transition economies. In balance of payments, exchange rates, and competitiveness in transition economies (pp. 19-93). Springer, Boston, MA.

Sabra, M. M. (2016). Remittances impact on economic growth, domestic savings and domestic capital at the presence of ODA and FDI in selected MENA countries. International Journal of Academic Research in Business and Social Sciences, 6(5), 2222-6990.

Sarwar, A., Hassan, M., \& Mahmood, T. (2015). Foreign aid and governance in Pakistan. Pakistan Economic and Social Review, 149-176.

Siddiqui, A. H., \& Iqbal, J. (2010). Trade openness and growth: An analysis of transmission mechanism in Pakistan, MPR A Paper No. 24534.

Solimano, A. (2003, May). Workers remittances to the Andean region: Mechanisms, costs and development impact: Inter-American Development Bank. Paper presented at the Multilateral Investment Fund-IDB's Conference on Remittances and Development, Quito-Ecuador.

Solow, R. M. (1956). A contribution to the theory of economic growth. The Quarterly Journal of Economics, 70(1), 65-94.

Spatafora, N., \& Aggarwal, R. (2005). Two current issues facing developing countries. World Economic Outlook, 69-107.

Sylwester, K. (2005). Foreign direct investment, growth and income inequality in less developed countries. International Review of Applied Economics, 19(3), 289-300.

Vargas-Silva, C., Jha, S., \& Sugiyarto, G. (2009). Remittances in Asia: Implications for the fight against poverty and the pursuit of economic growth. Asian Development Bank Economics Working Paper Series, (182). Manila: Asian Development Bank (ADB).

Wang, J. Y., \& Blomström, M. (1992). Foreign investment and technology transfer: A simple model. European Economic Review, 36(1), 137-155. 
Weisskopf, T. E. (1972). An econometric test of alternative constraints on the growth of underdeveloped countries. The Review of Economics and Statistics, 67-78.

Yılmazer, M. (2010). Doğrudan yabancı yatırımlar, dış ticaret ve ekonomik büyüme ilişkisi: Türkiye üzerine bir deneme. Celal Bayar Üniversitesi SBE, Sosyal Bilimler Dergisi, 8(1), 241-260.

\section{Corresponding author}

Shah Asadullah Mohd. Zobair can be contacted at: sam.zobair@yahoo.com 